\title{
SH3PXD2A wt Allele
}

National Cancer Institute

\section{Source}

National Cancer Institute. SH3PXD2A wt Allele. NCI Thesaurus. Code C99612.

Human SH3PXD2A wild-type allele is located in the vicinity of 10q25.1 and is approximately $267 \mathrm{~kb}$ in length. This allele, which encodes SH3 and PX domain-containing protein $2 \mathrm{~A}$, plays a role in the modulation of both signaling and cellular protrusion formation. 